Article

\title{
Control of Erigeron bonariensis with Thymbra capitata, Mentha piperita, Eucalyptus camaldulensis, and Santolina chamaecyparissus Essential Oils
}

\author{
Mercedes Verdeguer ${ }^{1, *} \mathbb{\infty}$, Luis Guillermo Castañeda ${ }^{1}$, Natalia Torres-Pagan ${ }^{1}$, \\ Juan Antonio Llorens-Molina ${ }^{1}$ and Alessandra Carrubba ${ }^{2}$ (D) \\ 1 Instituto Agroforestal Mediterráneo, Universitat Politècnica de València, Camino de Vera s/n, 46022 Valencia, \\ Spain; luicasag@posgrado.upv.es (L.G.C.); natorpa@upv.es (N.T.-P.); juallom2@qim.upv.es (J.A.L.-M.) \\ 2 Università degli Studi di Palermo, Dipartimento di Scienze Agrarie, Alimentari e Forestali, Viale delle \\ Scienze, Ed. 4, 90128 Palermo, Italy; alessandra.carrubba@unipa.it \\ * Correspondence: merversa@doctor.upv.es
}

Received: 25 November 2019; Accepted: 24 January 2020; Published: 28 January 2020

\begin{abstract}
In the search of sustainable and environmentally friendly methods for weed control, there is increasing interest in essential oils (EOs) as an approach to reduce synthetic herbicide use. The phytotoxicity of Thymbra capitata, Mentha piperita, Eucalyptus camaldulensis, and Santolina chamaecyparissus EOs against the noxious weed Erigeron bonariensis were evaluated in pre- and post-emergence assays in greenhouse conditions. The EOs were applied at 2, 4, and $8 \mu \mathrm{L} / \mathrm{mL}$, with Fitoil used as emulsifier. In post-emergence, two ways of application were tested, irrigation and spraying. Several germination parameters (germination \%, mean germination time, and synchrony of the germination process) were evaluated in pre-emergence tests, and the phytotoxicity level was assessed in post-emergence. In pre-emergence, all EOs significantly reduced seed germination as compared to the controls, ranking: T. capitata $>$ E. camaldulensis $>$ S. chamaecyparissus $>$ M. piperita. The effectiveness of all EOs varied with the tested dose, always following the rank $2 \mu \mathrm{L}<4 \mu \mathrm{L}<8 \mu \mathrm{L}$, with $T$. capitata EO showing full effectiveness even at the lowest dose. In post-emergence, T. capitata was the most effective EO, inducing a rather complete inhibition of plantlet growth at the highest two doses. These EOs demonstrated to have good potential for the formulation of natural herbicides.
\end{abstract}

Keywords: weed control; natural herbicides; essential oils; Erigeron bonariensis; pre-emergence; post-emergence; seed germination

\section{Introduction}

The world population is increasing continuously and is expected to reach 9.7 billion in 2050 and 11.1 billion in 2100 [1]. Furthermore, the size of arable land is limited and cannot be expanded without threatening vital natural habitats like the rain forests [2]. Other resources necessary for agricultural production, like water, energy, biodiversity, human labor, and fertilizers, are reducing as well [3]. The challenge to feed more people in this context is to increase agricultural production and food availability in a sustainable way. One key opportunity to reach this objective is to improve crop protection. Direct yield losses caused by pest (insects, pathogens, and weeds) range approximately between 20 and $40 \%$ of global agricultural productivity [4], but these numbers do not reflect the real cost that includes indirect losses caused to consumers, public health, societies, environments, economic fabrics, and farmers [3]. Overall, weeds decrease major crop potential yields up to $34 \%$, causing greater losses than diseases and pests [4]. Weeds reduce the quantity and quality of crop yields due to the competition for water, nutrients, light, and carbon dioxide, as well as by allelopathy [5]. 
There are different strategies for weed management, from cultural practices, like crop rotation or the use of more competitive crop varieties, to physical, mechanical, and biological control methods. However, since the discovery of the first herbicide, 2,4-dichlorophenoxyacetic acid (2,4-D), in 1940 [6], chemical control (herbicides application) has been the most used method to control weeds. The adoption of herbicides has contributed to the improvement of weed control [7], with a subsequent increase in crop yields, and has also led to a reduction of tillage operations, with a decrease in $\mathrm{CO}_{2}$ emissions associated with farming activities. However, their overuse promoted the development of resistant weeds, also affecting human health and causing environmental pollution [8].

All the aforementioned has led to the adoption of "Integrated Pest Management" (IPM) strategies, combining the different available control methods and promoting the search for alternatives to pesticides. Worldwide legislation has adopted the principles of IPM, such as the globally accepted International Code of Conduct on the Distribution and Use of Pesticides [9], the European Union Directive 2009/128/EC, or the US Food Quality Protection Act (FQPA) [10].

Natural products are an excellent alternative to synthetic pesticides as means to reduce negative impacts to human health and the environment. The need for developing new crop protection tools with novel modes of action makes the discovery and commercialization of natural products as green pesticides an attractive and profitable pursuit that is commanding attention [11].

Herbicides based on plant essential oils (EOs) have been demonstrated to be effective against a wide range of weeds and are a potential alternative to non-selective herbicides [12]. EOs from Thymus vulgaris, Satureja hortensis, Cinnamomum zeylanicum, and Syzygium aromaticum were phytotoxic and caused cell death to Chenopodium album, Ambrosia artemisiifolia, and Sorghum halepense [13]. Many studies have proved the herbicidal activity of Eucalyptus spp. EOs, for example, Eucalyptus camaldulensis EO, inhibited the germination and growth of Amaranthus hybridus and Portulaca oleracea [14], and the EO from E. citriodora was effective to control the invasive noxious weed Parthenium hysterophorus [15]. EOs from Lamiaceae and Asteraceae have also shown high potential for their use as natural herbicides [12,16,17].

Erigeron bonariensis L. (syn: Conyza bonariensis (L.) Cronquist, Asteraceae) has become one of the most troublesome weeds around the world due to its widespread occurrence, pronounced interference, and challenging management [18]. It is native to South America [19] and has invaded a large number of countries in Africa, Asia-Pacific, and Europe [20].

Some of the features that explain the colonizing success and high competitiveness of E. bonariensis are that it is an annual prolific species, capable of producing 200,000 viable seeds per plant and establishing under different environmental conditions [21]. The base, optimum, and maximum temperatures for seed germination were estimated at $4.2,20$, and $35^{\circ} \mathrm{C}$ [22]. The seeds show a dynamic ecology, which enables E. bonariensis to reproduce and proliferate in a wide range of temperatures, moistures, and soils in different cropping systems [23]. E. bonariensis adapts well to systems considered soil conservationists, such as tillage, minimum tillage, and orchard areas [24,25]. The factors that can contribute to its ecological adaptability, the survival of resistant biotypes, and the high infestations in conservation systems are self-pollination, along with a large production of easily dispersible seeds [26]. It has developed resistance to glyphosate (EPSP synthase inhibitor, group D), the most commercialized herbicide in the world today [21], as well as to chlorsulfuron (ALS inhibitors, group B), atrazine, and simazine (Photosystem II inhibitors, group C1), diquat, and paraquat (PSI Electron Diverter, group D) [27]. Many agricultural producers are facing problems to control this weed in different crops around the world [20-26].

The objective of this research was to study the phytotoxic potential of Thymbra capitata, Mentha piperita, Eucalyptus camaldulensis, and Santolina chamaecyparissus EOs against E. bonariensis with the purpose to find alternatives for the control of this problematic weed. These EOs have not been tested before on this weed.

The selection of the EOs was based on the previous knowledge of their herbicidal properties. T. capitata EO has been reported to inhibit the germination and growth of many weeds [28,29], including P. oleracea and Erigeron canadensis [30]. M. piperita EO showed phytotoxic activity against tomato 
crops (Lycopersicon esculentum), radish (Raphanus sativus) and the weeds P. oleracea, Convolvolus arvensis, and Echinochloa colonum [31]. The potential of E. camaldulensis EO to control different weeds has been demonstrated $[14,30]$. The EO from $S$. chamaecyparissus could be a promising alternative to synthetic herbicides as it was tested on seed germination and root and shoot growth of four crops (Zea mays, Triticum durum, Pisum sativum, and Lactuca sativa) and two weeds (P. oleracea and Vicia sativa) resulting to be less injurious to the crop species Z. mays and P. sativum as compared to the weeds [32].

\section{Results and Discussion}

\subsection{Pre-Emergence Treatments}

The results of the statistical analysis carried out on all germination measurements in the pre-emergence treatments (four EOs and two controls: C1, water and C2, water + Fitoil) are reported in Table 1 . After 40 days of observations, the total germination percentage value reached $28 \%$ in $\mathrm{C} 1$, whereas in C2 seed germination was almost twice as high (54\%). The highest values of seed germination were recorded in the two controls, above all C2, that apparently exerted a stimulation effect.

The strongest inhibitory effect was recorded in the pots treated with EOs of T. capitata, E. camaldulensis, and S. chamaecyparissus, where $0.67,8.00$, and $9.33 \%$ seeds germinated, respectively.

The same treatments showed the highest values of mean germination time (MT) as well. On average, pots-treated with EOs of T. capitata took 30 days for maximum germination, whereas E. camaldulensis and S. chamaecyparissus showed a MT of 27.78 and 21.67 days. Although these values were not significantly different from those recorded on the other treatments, all of them were different from both controls.

The values of germination variability coefficient $(\mathrm{CVt})$ showed a high variability in germination time; the calculated value was higher than $100 \%$ in all treatments and in the control C2 (water + Fitoil), and showed a lower value (about $45 \%$ ) only in the water control. No variability coefficient was calculated for the T. capitata treatment, since only one germination time value was present.

Mean germination rate (MR) evidenced low values, the minimum being in T. capitata and E. camaldulensis ( 0.03 and 0.05 , respectively). The two controls $C 1$ and $C 2$ showed the highest values, in both cases slightly higher than 0.1 seeds germinated/day.

The calculated uncertainty of the germination process (Uvalue) was zero for the T. capitata treatment, that means no peak of germination occurred; slightly higher values (although not significantly different) could be observed for S. chamaecyparissus, E. camaldulensis, and M. piperita $(0.05,0.07$, and 0.09, respectively), whereas a significant difference was observed for the C2 control (water + Fitoil).

Similarly to the variability coefficient $(\mathrm{CVt})$, the synchrony of the germination process ( $\mathrm{Z}$ index) for the T. capitata treatment was not possible to calculate; all the other treatments did not express significant differences. However, a higher degree of overlapping in seeds germination in the S. chamaecyparissus treatment is worth noticing. Low synchrony was detectable in the water control (C1), meaning that in that case, seed germination occurred rather gradually.

The lower part of Table 1 shows the effects of the different doses of each tested EO measured during the last survey date (day 40). In all tested EOs, a significant dose-effect occurred, and the inhibitory effect of all EOs was enhanced with increasing doses; at the highest two doses (4 and $8 \mu \mathrm{L} / \mathrm{mL})$, all EOs had a significantly different effect from the water control (C1). Unlike the other EOs, T. capitata exhibited a high effectiveness even at the lowest dose. 
Table 1. Germination measurements (mean \pm standard deviation) and results of ANOVA of seeds of Erigeron bonariensis treated in pre-sowing with essential oils (EOs) of Eucalyptus camaldulensis, Mentha piperita, Santolina chamaecyparissus, and Thymbra capitata at different doses. Treatment means followed by the same letters in each column are not significantly different at $\mathrm{P} \leq 0.05$ (Tukey's test). Within each DxT group, values not followed by the superscript "a" are not significantly different from the water control (C1) at $\mathrm{P} \leq 0.05$ (Dunnett's test). Prior to analyses, percent values were transformed into angular values.

\begin{tabular}{|c|c|c|c|c|c|c|c|c|c|c|c|c|c|c|}
\hline & & \multicolumn{2}{|r|}{ G (\%) } & \multicolumn{3}{|r|}{ MT (days) } & \multicolumn{2}{|r|}{ CVt (\%) } & \multicolumn{2}{|r|}{ MR $\left(\right.$ days $\left.^{-1}\right)$} & \multirow{2}{*}{\multicolumn{2}{|c|}{$\begin{array}{c}\text { U (bit) } \\
\text { DF Mean } \pm \text { st.dev. }\end{array}$}} & \multicolumn{2}{|r|}{$\mathrm{Z}$} \\
\hline & & DF & Mean \pm st.dev. & & DF & Mean \pm st.dev. & DF & Mean \pm st.dev. & DF & F $\quad$ Mean \pm st.dev. & & & DF & Mean \pm st.dev. \\
\hline \multicolumn{2}{|c|}{ Treatment $(\mathrm{T})$} & 5 & & & 5 & & 5 & & 5 & & 5 & & 4 & \\
\hline \multicolumn{2}{|c|}{ Water (C1) } & & $28.00 \pm 21.50$ & B & & $13.23 \pm 9.07$ & C & $42.10 \pm 35.75$ & B & $0.1033 \pm 0.0527$ & $\mathrm{AB}$ & $0.28 \pm 0.46$ & $\mathrm{AB}$ & $0.00 \pm 0.00$ \\
\hline \multicolumn{2}{|r|}{ Water + Fitoil (C2) } & & $54.00 \pm 18.97$ & A & & $9.96 \pm 2.82$ & B & $135.50 \pm 16.24$ & A & $0.1097 \pm 0.0387$ & $\mathrm{~A}$ & $0.56 \pm 0.49$ & A & $0.50 \pm 0.41$ \\
\hline \multicolumn{2}{|r|}{ E. camaldulensis } & & $8.00 \pm 13.49$ & $\mathrm{CD}$ & & $27.78 \pm 12.28$ & A & $149.73 \pm 13.17$ & A & $0.0474 \pm 0.0309$ & B & $0.07 \pm 0.25$ & B & $0.33 \pm 0.58$ \\
\hline \multicolumn{2}{|r|}{ M. piperita } & & $14.67 \pm 16.55$ & $\mathrm{BC}$ & & $19.32 \pm 10.14$ & A & $139.95 \pm 5.01$ & A & $0.0662 \pm 0.0307$ & $\mathrm{AB}$ & $0.09 \pm 0.34$ & B & $0.60 \pm 0.55$ \\
\hline \multicolumn{2}{|r|}{ S. chamaecyparissus } & & $9.33 \pm 15.52$ & $\mathrm{CD}$ & & $21.67 \pm 12.62$ & A & $142.24 \pm 1.42$ & A & $0.0767 \pm 0.0713$ & $\mathrm{AB}$ & $0.05 \pm 0.29$ & B & $0.67 \pm 0.58$ \\
\hline \multirow{2}{*}{\multicolumn{2}{|c|}{ T. capitata }} & & $0.67 \pm 3.65$ & $\mathrm{D}$ & & $30.00 \pm 00.00$ & A & & & $0.0333 \pm 0.0000$ & $\mathrm{AB}$ & $0.00 \pm 0.00$ & B & \\
\hline & & & $F(5,126)=27.82 * * *$ & & & $5,43)=8.46^{* * *}$ & & $F(5,18)=22.62^{* * *}$ & & $F(5,42)=3.53^{* *}$ & & $(5,126)=6.80^{* * *}$ & & $F(4,18)=1.49$ n.s. \\
\hline \multicolumn{2}{|c|}{ Dose (D) within treatment (T) } & 8 & & & 5 & & 1 & & 5 & & 8 & & 1 & \\
\hline \multirow[t]{3}{*}{ E. camaldulensis } & $2 \mu \mathrm{L}$ & & $18.00 \pm 17.51$ & & & $23.33 \pm 12.52$ & & $149.73^{\mathrm{a}} \pm 13.17$ & & $0.0573 \pm 0.0343$ & & $0.20 \pm 0.42$ & & $0.33 \pm 0.58$ \\
\hline & $4 \mu \mathrm{L}$ & & $6.00^{a} \pm 9.66$ & & & $36.67^{a} \pm 5.77$ & & & & $0.0278^{a} \pm 0.0048$ & & $0.00 \pm 0.00$ & & \\
\hline & $8 \mu \mathrm{L}$ & & $0.00^{\mathrm{a}} \pm 0.00$ & & & & & & & & & $0.00 \pm 0.00$ & & \\
\hline \multirow[t]{3}{*}{ M. piperita } & $2 \mu \mathrm{L}$ & & $32.00 \pm 13.98$ & & & $12.92 \pm 5.26$ & & $139.95 \pm 5.01$ & & $0.0851 \pm 0.0219$ & & $0.26 \pm 0.56$ & & $0.60 \pm 0.55$ \\
\hline & $4 \mu \mathrm{L}$ & & $10.00^{a} \pm 10.54$ & & & $28.00^{\mathrm{a}} \pm 4.47$ & & & & $0.0367^{a} \pm 0.0075$ & & $0.00 \pm 0.00$ & & \\
\hline & $8 \mu \mathrm{L}$ & & $2.00^{\mathrm{a}} \pm 6.32$ & & & $40.00^{\mathrm{a}} \pm 0.00$ & & & & $0.0250 \pm 0.0000$ & & $0.00 \pm 0.00$ & & \\
\hline \multirow[t]{3}{*}{ S. chamaecyparissus } & $2 \mu \mathrm{L}$ & & $18.00 \pm 19.89$ & & & $20.28 \pm 12.54$ & & $142.65^{\mathrm{a}} \pm 1.73$ & & $0.0770 \pm 0.0709$ & & $0.16 \pm 0.50$ & & $0.50 \pm 0.71$ \\
\hline & $4 \mu \mathrm{L}$ & & $6.00^{\mathrm{a}} \pm 9.66$ & & & $18.33 \pm 11.55$ & & & & $0.0933 \pm 0.0924$ & & $0.00 \pm 0.00$ & & \\
\hline & $8 \mu \mathrm{L}$ & & $4.00^{\mathrm{a}} \pm 12.65$ & & & $40.00 \pm 0.00$ & & $141.42 \pm 0.00$ & & $0.0250 \pm 0.0000$ & & $0.00 \pm 0.00$ & & $1.00 \pm 0.00$ \\
\hline \multirow[t]{4}{*}{ T. capitata } & $2 \mu \mathrm{L}$ & & $2.00^{\mathrm{a}} \pm 6.32$ & & & $30.00 \pm 0.00$ & & & & $0.0333 \pm 0.0000$ & & $0.00^{\mathrm{a}} \pm 0.00$ & & \\
\hline & $4 \mu \mathrm{L}$ & & $0.00^{a} \pm 0.00$ & & & & & & & & & $0.00^{a} \pm 0.00$ & & \\
\hline & $8 \mu \mathrm{L}$ & & $0.00^{\mathrm{a}} \pm 0.00$ & & & & & & & & & $0.00^{\mathrm{a}} \pm 0.00$ & & \\
\hline & & & $F(8,126)=7.33^{* * *}$ & & & $F(5,43)=5.83 * * *$ & & $F(1,18)<1$ n.s. & & $F(5,42)=1.55$ n.s. & & $\begin{array}{c}F(8,126)=1.29 \\
\text { n.s. }\end{array}$ & & $F(1,18)<1$ n.s. \\
\hline Error & & 126 & & & 43 & & 18 & & 42 & & 1 & & 18 & \\
\hline Total & & 139 & & & 53 & & 23 & & 52 & & 1 & & 23 & \\
\hline
\end{tabular}

G, seed germination (\%); MT, mean germination time (days); $\mathrm{CVt}$, germination variability coefficient $(\%)$; MR, mean germination rate (days $\left.{ }^{-1}\right)$; $\mathrm{U}$, uncertainty of the germination process (bit); $\mathrm{Z}$, synchrony of the germination process (adimensional). Significance of $F$ values: ${ }^{* *} 0.001<\mathrm{P} \leq 0.01 ; * * * \mathrm{P} \leq 0.001$; n.s., not significant. 
Further details on the outcome of the experiment may be retrieved from the data reported in Figures 1 and 2, that show the values of seeds germination (G\%) across all survey dates in each EO. Figure 1 shows the values obtained by averaging the administration doses, along with those recorded in the two controls. The highest germination levels were observed in the water + Fitoil control (C2) that kept values higher than all the other treatments, including the water control (C1). The C2 control reached its maximum value (54\%) in about 20 days, whereas the water control had a fast increase in the first 10 days, thereafter the germination of new seeds was slower. The germination percentage in the $\mathrm{C} 1$ control was rather always about one half than that recorded in the $\mathrm{C} 2$. A strong inhibitory effect on seeds germination shows up in the T. capitata treatment, where germination values were always lower than 1\%. A lower, although remarkable, effect can be seen in the pots treated with $E$. camaldulensis and S. chamaecyparissus, where germination reached 8.0 and $9.3 \%$, respectively. Although always lower than in the water control, germination in pots treated with EO of M. piperita proved a significant difference with $\mathrm{C} 1$ only in few survey dates at ANOVA. In all other treatments, germination was slow and constantly below that measured on the control.

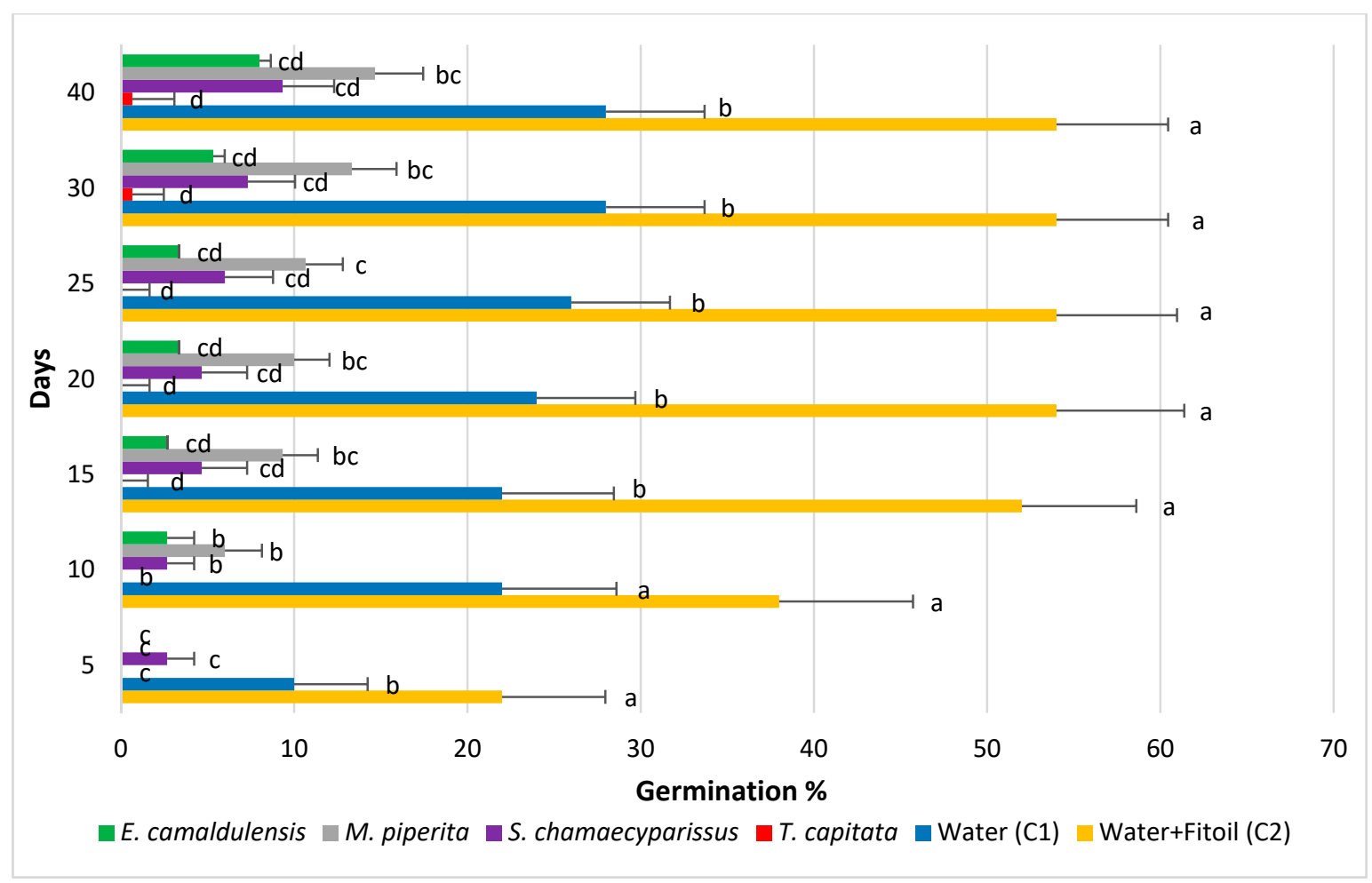

Figure 1. Percentage of seed germination in Erigeron bonariensis exposed to four EOs, compared with two controls (C1, water and C2, water + Fitoil). Error bars correspond to the standard error of each mean. For each observation day, means followed by the same letter are not statistically different (Tukey's test, $\mathrm{P} \leq 0.05)$. 


\section{T. capitata}

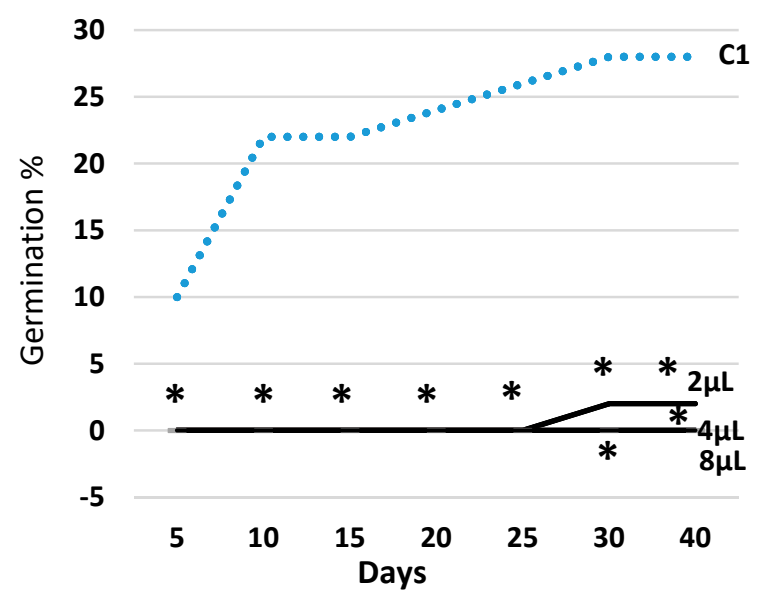

E. camaldulensis

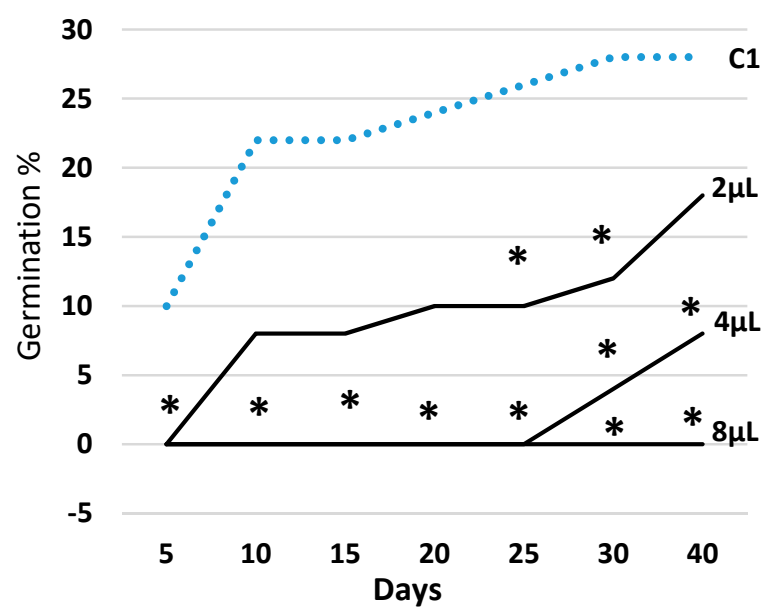

M. piperita

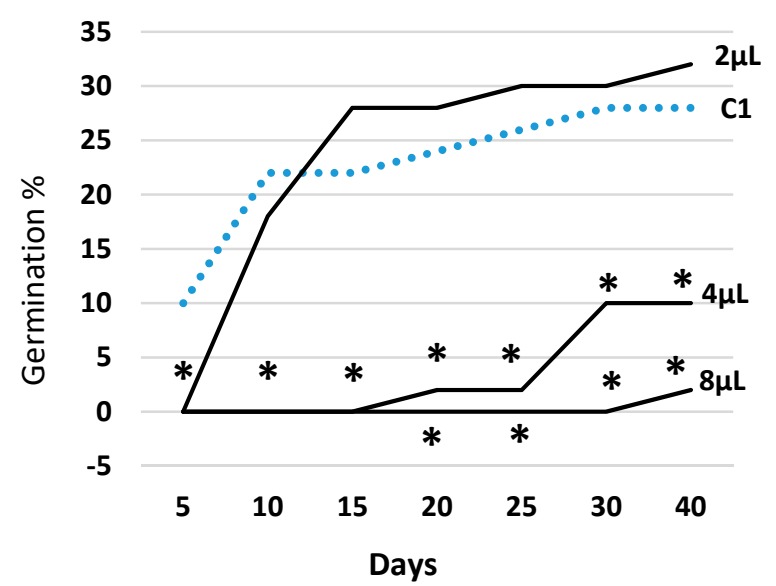

Figure 2. Cont. 


\section{S. chamaecyparissus}

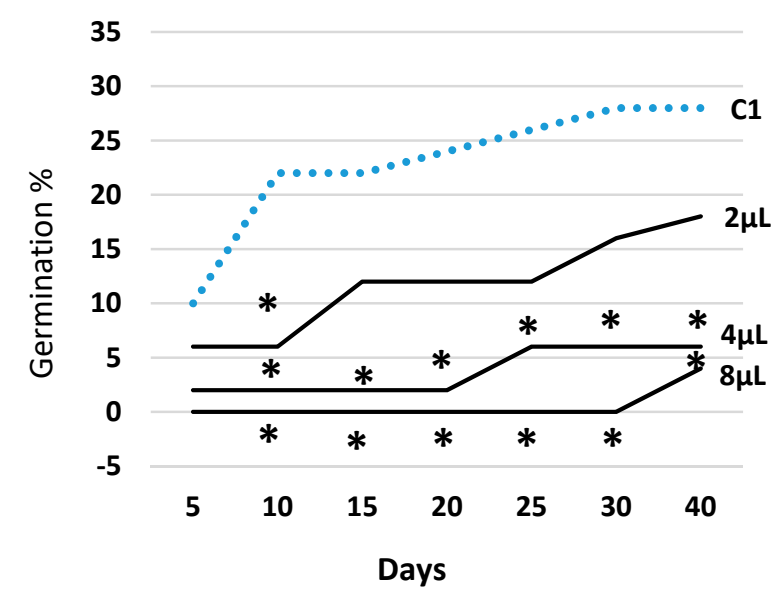

Figure 2. Trend over time of percent seed germination (cumulated values) in Erigeron bonariensis exposed to four EOs at three doses $(2 \mu \mathrm{L}, 4 \mu \mathrm{L}, 8 \mu \mathrm{L})$. For each observation day, values marked with * are significantly different from the water control ( $\mathrm{C} 1$; dotted line) at $\mathrm{P} \leq 0.05$ (Dunnett's test).

Figure 2 illustrates the trend over time of germination in all EOs and tested doses $(2,4$, and $8 \mu \mathrm{L}$ ) along with the data obtained in the water control (C1). The effectiveness of all EOs varied with the tested dose, always following the rank $2 \mu \mathrm{L}<4 \mu \mathrm{L}<8 \mu \mathrm{L}$. T. capitata EO was effective from the very start of the experiment, and in all survey dates, all three doses were statistically different from the water control (C1). The EOs of E. camaldulensis and S. chamaecyparissus showed a rather similar effectiveness over time and, when administrated at the lowest dose $(2 \mu \mathrm{L})$, they-with the exception of few observations - did not behave differently from the water control (C1). Otherwise, the two highest doses $(4 \mu \mathrm{L}$ and $8 \mu \mathrm{L})$ allowed a significant reduction of seeds germination in all survey dates. The EO of M. piperita expressed a significant effectiveness at the two highest doses as well, but at the lowest dose $(2 \mu \mathrm{L})$, starting from the third survey date (15 days), it showed even higher germination values than the water control (C1).

\subsection{Post-Emergence Treatments}

Table 2 shows the results of the ANOVA carried out on the values of the phytotoxicity level (PL \%) calculated based on the measurements of plants' diameters that were taken on all survey dates.

As shown, many significant $F$ values appear in all first and second order interactions; hence, although some information may be driven by the observation of the mean values, additional analysis was required in order to gain complete information from the data. At first sight, the spraying method would seem more effective than watering, but a low significance level $(\mathrm{P}<0.05)$, together with the occurrence of a highly significant interaction in rather all combinations of factors where $\mathrm{M}$ is included, does not allow any generalization. The observation of the "day" (d) factor allows detecting a trend in the expression of phytotoxicity, that appears to be growing until day 15; thereafter, and to the end of the experiment, it stops increasing. The observation of the "treatment" (T) effect allows very well discriminating between the two controls ( $\mathrm{C} 1$ and $\mathrm{C} 2)$ by one side, where the presence of high negative values demonstrates a continuous growth of the untreated plantlets, and all treatments, by the other side, that exert, on average, a definite (although variable) inhibitory effect. 
Table 2. Phytotoxicity level (mean \pm standard deviation of main effects) and results of ANOVA on Erigeron bonariensis plantlets exposed to four EOs, applied by watering or spraying, at different doses and evaluated at $1,5,10,15,20,25$, and 30 days after treatment.

\begin{tabular}{|c|c|c|c|}
\hline \multirow[b]{2}{*}{ Source } & & \multicolumn{2}{|c|}{ Phytotoxicity } \\
\hline & & DF & Mean \pm st. dev. \\
\hline & Method of application (M) & 1 & \\
\hline & Watering & & $11.85 \pm 47.38$ \\
\hline & Spraying & & $15.81 \pm 46.41$ \\
\hline & & & $F(1,2148)=4.73 *$ \\
\hline & day $(\mathrm{d})$ & 6 & \\
\hline & 1 & & $2.59 \pm 21.07$ \\
\hline & 5 & & $4.33 \pm 22.52$ \\
\hline & 10 & & $17.87 \pm 51.99$ \\
\hline & 15 & & $20.08 \pm 52.26$ \\
\hline & 20 & & $16.76 \pm 53.92$ \\
\hline & 25 & & $16.56 \pm 54.66$ \\
\hline & 30 & & $18.62 \pm 53.54$ \\
\hline & & & $F(6,2148)=9.33^{* * *}$ \\
\hline & Treatment (T) & 5 & \\
\hline & Water (C1) & & $-16.28 \pm 25.75$ \\
\hline & Water + Fitoil (C2) & & $-18.66 \pm 26.76$ \\
\hline & E. camaldulensis & & $17.42 \pm 45.48$ \\
\hline & M. piperita & & $21.67 \pm 42.36$ \\
\hline & S. chamaecyparissus & & $1.08 \pm 33.84$ \\
\hline & T. capitata & & $56.9 \pm 49.34$ \\
\hline & & & $F(5,2148)=271.91^{* * *}$ \\
\hline & Dose within treatment $(\mathrm{T})$ & 8 & $F(8,2148)=61.2^{* * *}$ \\
\hline & $M^{*} d$ & 6 & $F(6,2148)<1$ n.s. \\
\hline & $\mathrm{M}^{*} \mathrm{~T}$ & 5 & $F(5,2148)=48.87^{* * *}$ \\
\hline & $\mathrm{d}^{*} \mathrm{~T}$ & 30 & $F(30,2148)=9.19^{* * *}$ \\
\hline & $\mathrm{M}^{*} \mathrm{~d}^{*} \mathrm{~T}$ & 30 & $F(30,2148)=2.38^{* * *}$ \\
\hline Error & & 2148 & \\
\hline Total & & 2239 & \\
\hline
\end{tabular}

The direction and the intensity of this inhibitory effect are illustrated in Figure 3, where the phytotoxicity level of each extract and application method is reported, independently from the used dose, for each survey date.

As shown, all the controls lie on the left side of the graph (beyond the zero axis), showing no phytotoxicity at all; in these cases, the negative values of the PL index throughout the trial even testify an undisturbed growth of plantlets. Overall, the administration by spraying was most effective in the $\mathrm{EO}$ of T. capitata, whereas watering gave the best results in the EO of E. camaldulensis; the other two EOs did not show significant differences between the two supply methods.

The EO of T. capitata was the most effective in both administration ways; when sprayed, it reached very quickly (10 days after treatment) a phytotoxicity level close to $100 \%$. When applied by watering, it still kept a phytotoxicity level higher than all other EOs, but the statistical test demonstrates that its efficacy was, on average, similar to that expressed by the EOs of E. camaldulensis (watered) and M. piperita (sprayed). 


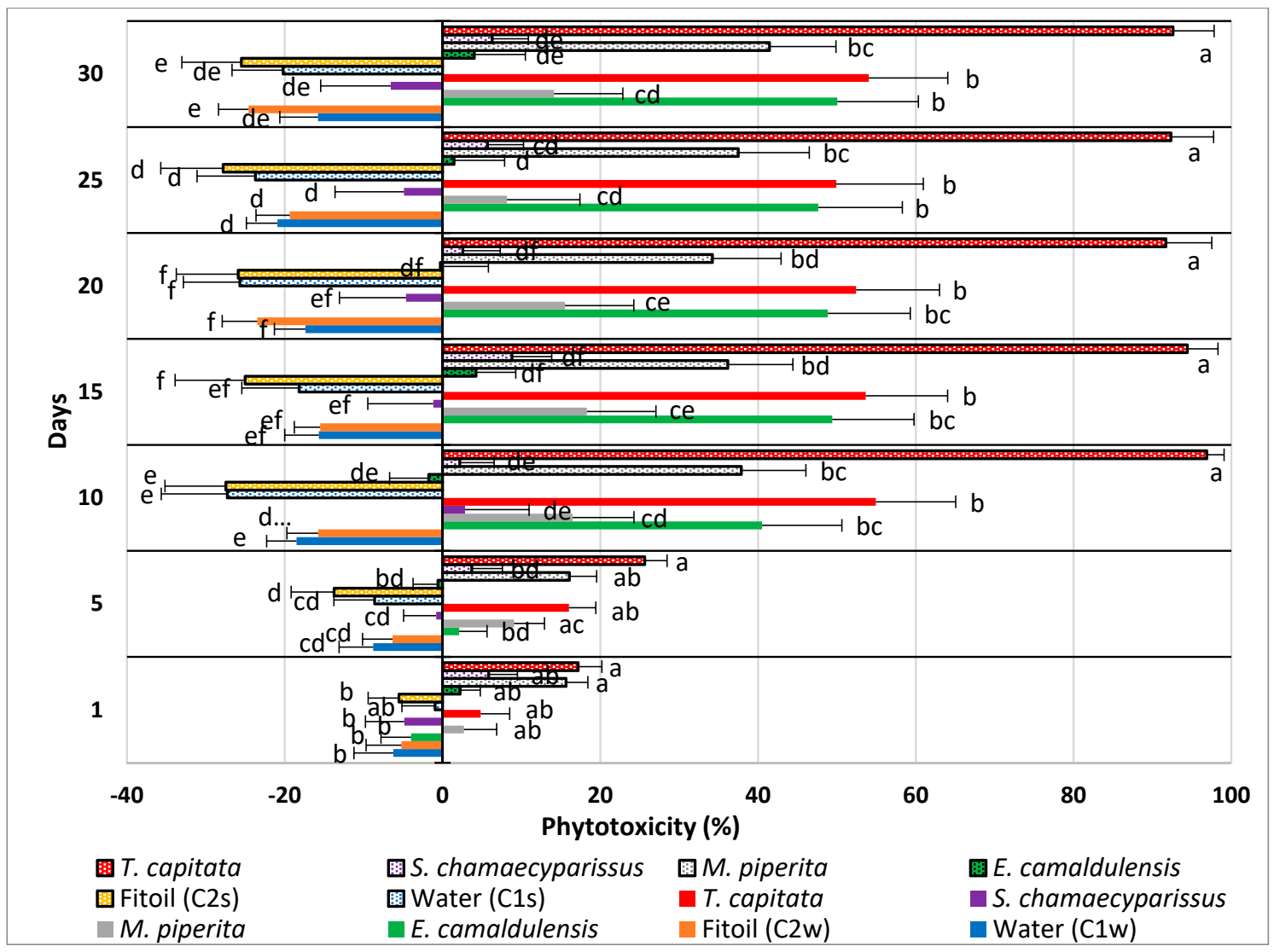

Figure 3. Calculated phytotoxicity level (\%) of 4 EOs, distributed by spraying (spotted bars) and watering (full-colored bars) on seedlings of Erigeron bonariensis. Error bars indicate the standard error of each mean. For each survey date, values accompanied by the same letter are significantly not different (Tukey's test, $\mathrm{P} \leq 0.05$ ).

The EO of E. camaldulensis was the second most effective EO, but only when administered by watering. This one was the only EO that showed a statistically higher effectiveness when applied by watering; when sprayed, it did not show significant differences from the respective controls (C1s and C2s).

The EO of S. chamaecyparissus showed weak effectiveness only when sprayed, whereas it exhibited no effect at all when watered. In both forms, however, it did not show any statistically significant difference from the controls.

The EOs of M. piperita and S. chamaecyparissus had statistically the same effectiveness in both application methods. Compared with the respective controls, the first one (M. piperita), when sprayed, showed a phytotoxicity level higher than the controls starting from day 10, whereas no differences occurred in the watered treatments. The second EO (S. chamaecyparissus) did not show any difference from the controls in both application methods.

Figure 4 shows the trend over time of the measured phytotoxicity level in each EO, application method, and tested dosage ( $2 \mu \mathrm{L}, 4 \mu \mathrm{L}$, and $8 \mu \mathrm{L}$ ), along with the data obtained in the respective water controls ( $\mathrm{CW}_{\mathrm{w}}$-watered and $\mathrm{Cs}$ - sprayed). In all cases, a strong dose-effect occurred, and the calculated phytotoxicity was growing with the applied dose $(2 \mu \mathrm{L}<4 \mu \mathrm{L}<8 \mu \mathrm{L})$. The EO of T. capitata was the most effective of all, especially when sprayed. In this case, at the higher doses $(4 \mu \mathrm{L}$ and 8 $\mu \mathrm{L}$ ), it started showing its effectiveness from the very beginning of the experiment (day 1), allowing an effectiveness close to $100 \%$ since the 10th day of observation. At the lowest dose $(2 \mu \mathrm{L})$, this EO proved a higher effectiveness when sprayed. When applied by watering, the phytotoxic effect of T. capitata was lower, although, in the last survey, it was, however, significantly different from the 
control. The E. camaldulensis EO was the only one showing a higher effectiveness when administered by watering; at the highest dose $(8 \mu \mathrm{L})$ it showed complete effectiveness (100\% phytotoxicity) since the 10th day of observation, showing no statistical difference with the $8 \mu \mathrm{L}$ treatment. When sprayed, the E. camaldulensis EO showed a lower phytotoxicity level (about 38\% at the highest dose), although statistically well differentiated from the water control at the end of the experiment (day 30 ). The $S$. chamaecyparissus EO was the less effective of all; on day 30 and at $8 \mu \mathrm{L}$, it reached a phytotoxicity level of about $30 \%$ (with watering distribution) and 21\% (after spraying).

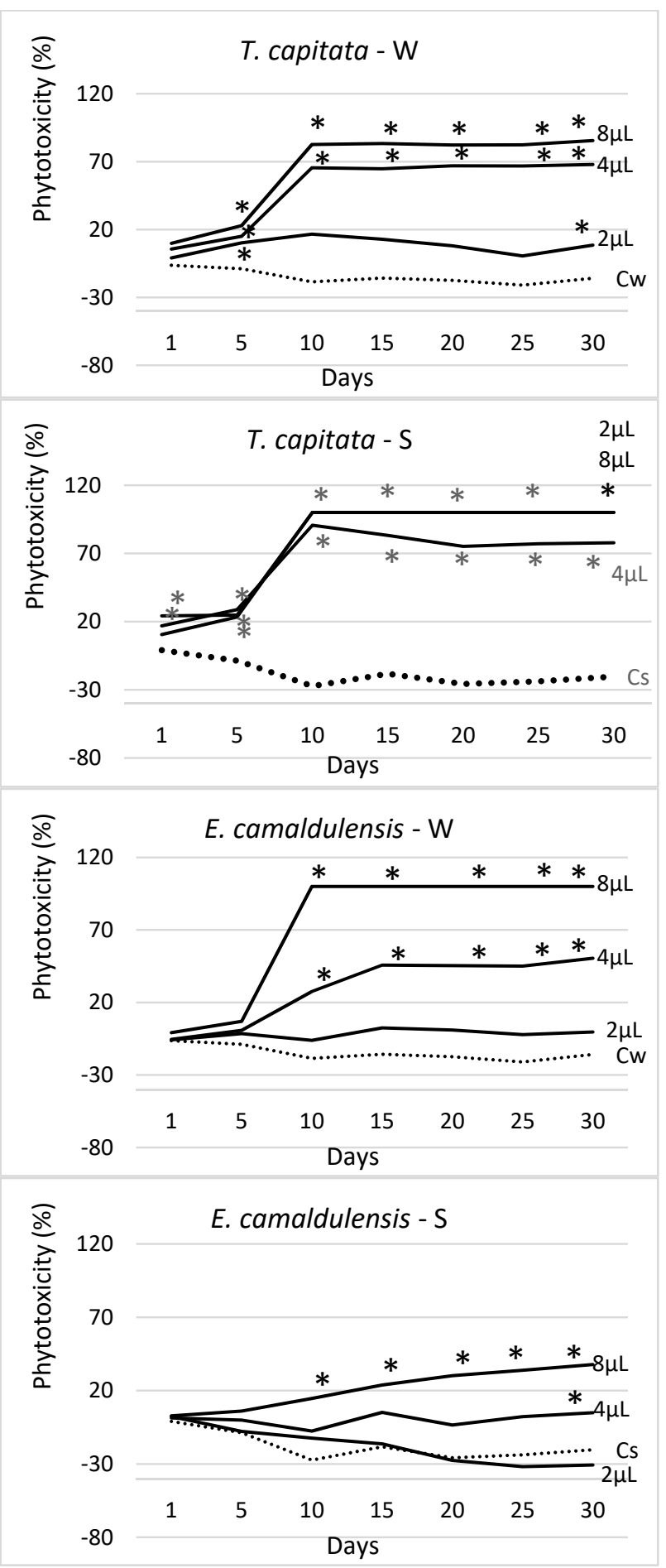

Figure 4. Cont. 


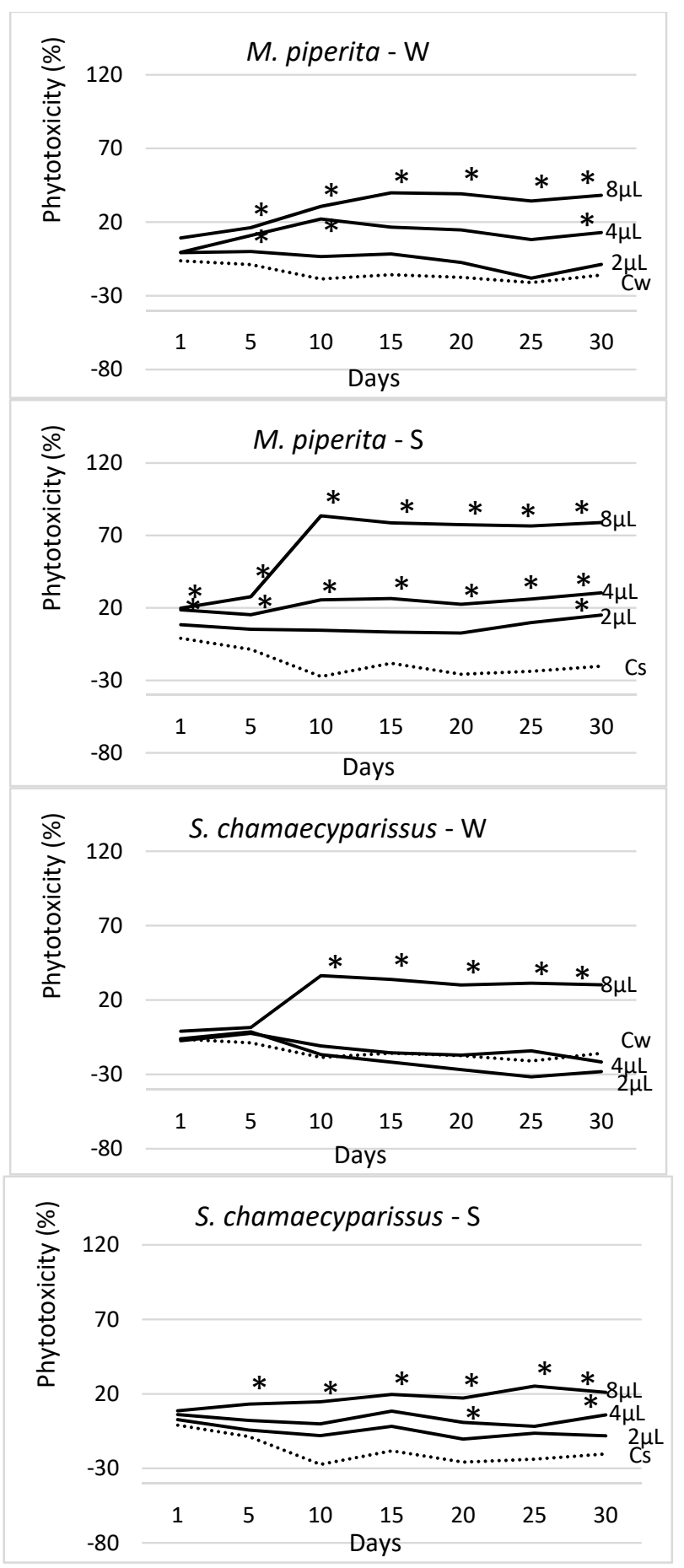

Figure 4. Trend over time of the phytotoxicity level (\%) of 4 EOs at three doses $(2 \mu \mathrm{L}, 4 \mu \mathrm{L}, 8 \mu \mathrm{L})$, distributed by watering (W) and spraying (S) on seedlings of Erigeron bonariensis. For each observation day, values marked with * are significantly different from the respective water controls ( $\mathrm{Cw}$ and $\mathrm{Cs}$; dotted lines) (Dunnett's test, $\mathrm{P} \leq 0.05$ ).

\subsection{Essential Oils Composition}

A total of 17 compounds were identified in T. capitata EO (Table 3) accounting for $99.80 \%$ of the EO composition. This EO was characterized for a high content of carvacrol $(72.30 \%)$, which was the main compound, followed by $p$-cymene (8.93\%) and $\gamma$-terpinene (7.77\%). In literature, three chemotypes of $T$. capitata have been reported: thymol, carvacrol, and thymol/carvacrol $[32,33]$. Our sample was 
carvacrol-type, characterized by high contents of this compound and also by the presence of p-cymene and $\gamma$-terpinene in different quantities [32-34]. The herbicidal activity of EOs rich in carvacrol from T. capitata and other species, as well as of the single compound has been largely studied, although the majority of experiments were performed in in vitro conditions [30,35-38]. Seeds of Sinapis arvensis soaked for $30 \mathrm{~min}$ in a solution of $1.5 \mu \mathrm{L} / \mathrm{mL}$ T. capitata EO (83.86\% carvacrol), dissolved in Tween 20 $(0.1 \%)$, and then placed on double-layered moistened Whatman No. 1 filter paper in Petri dishes, did not germinate after 10 days of watering [35]. T. capitata EO (carvacrol 69.15\%) also completely inhibited S. arvensis germination and strongly reduced that of Phalaris canariensis and Lolium rigidum at $1 \mu \mathrm{L} / \mathrm{mL}$ in vitro experiments [29]. In our previous studies, Erigeron canadensis and P. oleracea germination was blocked at 0.5 and $1 \mu \mathrm{L} / \mathrm{mL}$ by T. capitata EO (77.02\% carvacrol) in Petri dishes [30]. E. canadensis is taxonomically very close to E. bonariensis, so we presumed that this EO could exert good herbicidal activity against $E$. bonariensis as well. We also tested pure carvacrol against both weed germinations, preventing it in both species at concentrations starting from $0.0125 \mu \mathrm{L} / \mathrm{mL}$ up to $1 \mu \mathrm{L} / \mathrm{mL}$, hence we deduced that it was responsible for the herbicidal activity, as suggested by many authors [35-40]. It has been suggested that the mode of action of carvacrol as allelochemical is via membrane leakage at high dosages and extensive exposure duration [41].

M. piperita EO was constituted by 35 compounds (99.66\%) (Table 3), with menthol (51.81\%) and menthone $(20.52 \%)$ being the most abundant, followed by menthyl acetate $(6.56 \%)$. These are the typical main components of peppermint EO [42-46]. The phytotoxic potential of the EO and water extracts from $M$. piperita is well known [31,47]. The herbicidal activity of $M$. piperita EO has been demonstrated against different weed species in vivo, in greenhouse conditions, but it has never been tested on E. bonariensis. It was evaluated to control Amaranthus retroflexus, S. arvensis, and Lolium spp. germination at concentrations of 5.4, 21.6, 86.4, and $345.6 \mathrm{mg} / \mathrm{L}(\mathrm{C} 1-\mathrm{C} 4)$. The $\mathrm{C} 3$ dose exerted the maximum inhibitory activity for ryegrass $(62 \%)$, and wild mustard $(44 \%)$, while inhibited redroot pigweed 71\%. Instead, C4 showed higher inhibition ability only for redroot pigweed (82\%), while for wild mustard (32\%) and ryegrass (53\%) the inhibition was lower than with C3 [48]. A study was conducted to evaluate the stability and other physicochemical properties of some oil-in-water emulsions of $M$. piperita $\mathrm{EO}$ with commercially available adjuvants and mixtures with citric or acetic acid, and to determine the short-term phytotoxicity of foliar application of these emulsions and mixtures on Avena fatua and Chenopodium album in greenhouse experiments [45]. None of the emulsions or mixtures under study exhibited satisfactory stability. The emulsions of $M$. piperita $\mathrm{EO}$ had a significant herbicidal effect against C. album. None of the adjuvants tested significantly improved the efficacy. The herbicidal effect of emulsions against $A$. fatua depended on the greenhouse temperature, with treatments more effective at higher temperatures. M. piperita EO alone induced considerable short-term herbicidal effects. Some adjuvants improved its efficacy shortly after application, but due to regrowth no significant effects on biomass were obtained at harvest. The addition of adjuvants can improve the herbicidal effects of this EO, but further research is necessary [45]. Maffei et al. [46] contributed to determine the mode of action of M. piperita $\mathrm{EO}$ and its main components, as they were assessed for their ability to interfere with plant plasma membrane potentials. The main component responsible for the depolarization of the membrane was (-)-menthol, followed by (-)-menthone. The results of this study suggested that decreasing water solubility of monoterpenes increases the possibility for terpenoids to interact with and disrupt membrane integrity, thus causing a rapid and irreversible membrane potential depolarization. Since these monoterpenes can cause such extensive membrane depolarization, they are clearly toxic to plant cells. Changes in the bioelectric potential of cells imply changes in the flux of ions across the plasma membrane [46].

The EO from E. camaldulensis was rich in the oxygenated sesquiterpene spathulenol (31.29\%) (Table 3), and also $p$-cymene (20.36\%) and cryptone (17\%) were important constituents. A total of 25 compounds were identified representing $90.69 \%$ of the EO composition. These results are similar to those reported by Verdeguer et al. [14,30]. Furthermore, the EOs from E. camaldulensis growing in South Florida, Jerusalem, and Greece were characterized for containing spathulenol, p-cymene, 
and cryptone as main compounds, and small quantities of 1,8-cineol [49-51]. In previous studies, $E$. camaldulensis EO has shown good herbicidal potential, completely blocking the germination of different weed species (Amaranthus hybridus, Portulaca oleracea, Conyza canadensis, and Parietaria judaica), and reducing $57 \%$ that of $C$. album in in vitro tests $[14,30]$. The herbicidal activity of E. camaldulensis EO rich in 1,8-cineol (32.85\%) and p-cymene (23.95\%) was tested to control Convolvulus arvensis, Melilotus officinalis, and Amaranthus retroflexus in in vitro conditions. It was ineffective on root and stem growth of $C$. arvensis at 5,10 , and $20 \mu \mathrm{L}$ concentrations during seven days, while it was effective on root growth of $M$. officinalis and A. retroflexus at the same concentrations during seven days [52]. The EO from $E$. cladocalyx cultivated in Morocco, which main compounds were spathulenol (21.6\%) and 1,8-cineole $(20.5 \%)$, followed by p-cymene $(15.1 \%)$, showed herbicidal activity against S. arvensis [53]. To our knowledge, E. camaldulensis $\mathrm{EO}$ has never been tested against $E$. bonariensis in in vivo conditions so far. Its herbicidal activity could be due to the high content of spathulenol and carvone. The isolated compounds, p-cymene and carvone, and other EO components, were tested against Lolium rigidum. Carvone was between the most phytotoxic compounds, completely inhibiting germination and root length of L. rigidum at $160 \mathrm{~nL} / \mathrm{cm}^{3}$ or above, also showing synergistic activity with carvacrol, thymol, and linalool, while $p$-cymene was slightly phytotoxic [38]. However, the herbicidal activity of isolated spathulenol has not been verified yet, because it cannot be purchased and is difficult and expensive to isolate in great quantities as to be tested in in vivo conditions.

S. chamaecyparissus EO possessed the lower content in oxygenated compounds as compared to the other EOs studied (Table 3). Four components were the most abundant: 1,8-cineole (17.50\%), viridiflorol $(13.56 \%)$, germacrene-D $(12.60 \%)$, and 8-methylene-3-oxatricyclo $[5,2,0,0(2,4)]$ nonane $(12.24 \%)$. In this EO, 39 compounds were identified (98.95\%). The compositions of S. chamaecyparissus EOs from different origins have been studied and are very divergent, changing the major compounds and also the number of compounds identified and their abundance [54-59]. In some of the studied samples, 1,8-cineole was reported among the most abundant compounds $[55,57,59]$. The herbicidal effect of $S$. chamaecyparissus EO rich in 1,8-cineole (24.8\%) was investigated on seed germination and root and shoot growth of four crops (Zea mays, Triticum durum, Pisum sativum, and Lactuca sativa) and two weeds (Portulaca oleracea and Vicia sativa). It inhibited the germination of both weeds and also of wheat and lettuce and was less harmful for sweet corn and dwarf pea. Regarding the effect on shoot and root length, it was more active on P. oleracea than on the crops [57]. The essential oil of S. chamaecyparissus from an industrial sample (containing 9.8\% of 1,8-cineole and 8.2\% of 8-methylene-3-oxatricyclo [5.2.0.02,4] nonane as main compounds) showed a moderate phytotoxicity against the leaf growth of $L$. perenne, but did not show negative effects against $L$. sativa seeds [59]. It has been suggested that $S$. chamaecyparissus EO could be a promising alternative to synthetic herbicides [57,59]. All studies about the herbicidal activity of $S$. chamaecyparissus EO were performed in in vitro conditions. It is the first time that it is tested in vivo and against E. bonariensis. As S. chamaecyparissus EOs are constituted by a complex mixture of compounds, it has been reported that its activity is due to the synergistic activity of those components [57,58]. 
Table 3. Chemical composition of Thymbra capitata (TC), Mentha piperita (MP), Eucalyptus camaldulensis (EC), and Santolina chamaecyparissus (SC) EOs.

\begin{tabular}{|c|c|c|c|c|c|}
\hline Component & KI. & TC & MP & EC & SC \\
\hline Monoterpene hydrocarbons & & 22.54 & 1.95 & 22.27 & 9.30 \\
\hline Santolina triene & 908 & - & - & - & 0.13 \\
\hline$\alpha$-Thujene & 930 & 0.89 & 0.01 & 0.43 & - \\
\hline$\alpha$-Pinene & 938 & 0.74 & 0.28 & - & 0.85 \\
\hline Thuja-2,4(10)-diene & 947 & - & - & 0.10 & - \\
\hline Camphene & 951 & - & - & - & 0.28 \\
\hline Sabinene & 975 & - & 0.14 & 0.09 & 0.17 \\
\hline$\beta$-Pinene & 978 & 0.29 & 0.43 & - & 3.98 \\
\hline Myrcene & 991 & 1.95 & 0.01 & 0.08 & - \\
\hline$\alpha$-Phellandrene & 1004 & 0.16 & - & 0.11 & - \\
\hline$\gamma$-Terpinene & 1016 & 7.77 & 0.13 & 0.12 & 1.18 \\
\hline$\alpha$-Terpinene & 1016 & 1.61 & - & - & 0.69 \\
\hline$p$-Cymene & 1025 & 8.93 & 0.18 & 20.36 & 2.01 \\
\hline Limonene & 1029 & 0.20 & 0.73 & 0.87 & - \\
\hline (Z)- $\beta$-Ocimene & 1040 & - & 0.03 & - & - \\
\hline iso-Terpinolene & 1087 & - & 0.02 & - & - \\
\hline p-Cymenene & 1090 & - & - & 0.11 & - \\
\hline Oxygenated monoterpens & & 73.98 & 95.35 & 33.76 & 39.32 \\
\hline 1,8-Cineole & 1031 & 0.11 & 4.31 & 2.31 & $\mathbf{1 7 . 5 0}$ \\
\hline trans-Pinocarveol & 1037 & - & - & - & 0.17 \\
\hline Artemisia ketone & 1062 & - & - & - & 4.63 \\
\hline (Z)-Sabinene hydrate & 1070 & - & 0.76 & - & - \\
\hline Linalool & 1097 & 0.77 & 0.09 & - & 0.42 \\
\hline trans-Thujone & 1117 & - & - & 0.19 & - \\
\hline Camphor & 1142 & - & - & - & 4.03 \\
\hline Menthone & 1154 & - & 20.52 & - & - \\
\hline (E)-Pinocamphone & 1159 & - & - & - & 0.18 \\
\hline (Z)-Chrysanthemol & 1162 & - & - & - & 3.80 \\
\hline Menthofuran & 1163 & - & 5.21 & - & - \\
\hline neo-Menthol & 1165 & - & 3.12 & - & - \\
\hline Borneol & 1168 & 0.16 & - & - & 1.11 \\
\hline (Z)-Pinocamphone & 1172 & - & - & - & 2.03 \\
\hline Menthol & 1175 & - & 51.81 & - & - \\
\hline Terpinen-4-ol & 1177 & 0.37 & 0.67 & 2.89 & 2.69 \\
\hline iso-menthol & 1182 & - & 0.60 & - & - \\
\hline Neoisomenthol & 1187 & - & 0.08 & - & - \\
\hline$\alpha$-Terpineol & 1188 & - & 0.17 & 0.93 & 0.21 \\
\hline Myrtenal & 1192 & - & - & - & 1.31 \\
\hline Myrtenol & 1193 & - & - & - & 1.07 \\
\hline Cryptone & 1196 & - & - & 17.00 & - \\
\hline Verbenone & 1198 & - & - & - & 0.16 \\
\hline$m$-Cumenol & 1230 & - & - & 0.46 & - \\
\hline Pulegone & 1236 & - & 0.83 & - & - \\
\hline Cumin aldehyde & 1245 & & - & 4.15 & - \\
\hline Carvotanacetone & 1250 & - & - & 0.33 & - \\
\hline Piperitone & 1251 & - & 0.32 & - & - \\
\hline neo-Menthyl acetate & 1273 & - & 0.16 & - & - \\
\hline p-Menth-1-en-7-al & 1279 & - & - & 2.85 & - \\
\hline Menthyl acetate & 1291 & - & 6.56 & - & - \\
\hline Thymol & 1292 & 0.27 & - & 1.14 & - \\
\hline Carvacrol & 1300 & 72.30 & - & 1.51 & - \\
\hline iso-Menthyl acetate & 1303 & - & 0.16 & - & - \\
\hline
\end{tabular}


Table 3. Cont.

\begin{tabular}{|c|c|c|c|c|c|}
\hline Component & KI. & TC & MP & EC & SC \\
\hline Sesquiterpene hydrocarbons & & 3.14 & 2.22 & 0.19 & 21.78 \\
\hline$\alpha$-Ylangene & 1373 & - & - & - & 0.08 \\
\hline$\alpha$-Bourbonene & 1381 & - & 0.17 & - & - \\
\hline$\beta$-Caryophyllene & 1415 & 3.14 & 1.47 & - & 0.39 \\
\hline$\beta$-Farnesene & 1454 & - & 0.02 & - & - \\
\hline allo-Aromadendrene & 1457 & - & - & 0.19 & 4.23 \\
\hline trans-Cadina-1(6),4-diene & 1473 & & & & 0.36 \\
\hline Germacrene-D & 1477 & - & 0.42 & - & 12.60 \\
\hline$\beta$-Selinene & 1491 & - & 0.13 & - & - \\
\hline Elixene & 1492 & - & - & - & 2.80 \\
\hline$\gamma$-Cadinene & 1509 & - & - & - & 0.32 \\
\hline$\delta$-Cadinene & 1519 & - & - & - & 1.00 \\
\hline Oxygenated sesquiterpenes & & 0.14 & 0.00 & 34.47 & 15.64 \\
\hline Bornyl acetate & 1283 & - & - & - & 0.08 \\
\hline Spathulenol & 1477 & - & - & 31.29 & 1.42 \\
\hline Caryophyllene oxide & 1577 & 0.14 & - & - & 0.19 \\
\hline Viridiflorol & 1587 & - & - & 0.54 & 13.56 \\
\hline$\beta$-Oplopenone & 1602 & - & - & - & 0.16 \\
\hline Spathulenol isomer & 1616 & - & - & 1.29 & - \\
\hline iso-spathulenol & 1640 & - & - & 1.35 & - \\
\hline$\alpha$-Cadinol & 1649 & - & - & - & 0.23 \\
\hline Others & & 0.00 & 0.14 & 0.00 & 12.91 \\
\hline 1-Butanol, 2-methyl-, propanoate & 973 & - & - & - & 0.20 \\
\hline 1-Octen-3-ol & 980 & - & 0.02 & - & - \\
\hline 3-Octanol & 995 & - & 0.07 & - & - \\
\hline iso-Amyl 2-methyl butyrate & 1101 & - & 0.02 & - & - \\
\hline n-Amyl isovalerate & 1106 & - & 0.04 & - & 0.48 \\
\hline $\begin{array}{l}\text { 8-methylene-3-oxatricyclo[5,2,0,0(2,4)] } \\
\text { nonane }\end{array}$ & 1117 & - & - & - & 12.24 \\
\hline TOTAL IDENTIFIED (\%) & & 99.80 & 99.66 & 90.69 & 98.95 \\
\hline
\end{tabular}

In bold, the most significant compounds for each EO.

\section{Materials and Methods}

\subsection{Erigeron Bonariensis L. Seeds}

The tested seeds were collected from Erigeron bonariensis L. plants growing wild in a citrus orchard in the town of Villatorcas (Castellón province, Segorbe, Spain) in July 2016. The botanical identification was performed by the authors using the available specific literature [60]. Before using them in the trials, their germination capability was verified. In vitro germination tests were performed in a germination chamber from Equitec with controlled temperature and light. The chamber conditions were $30^{\circ} \mathrm{C}$ $16 \mathrm{~h}$ light and $20^{\circ} \mathrm{C} 8 \mathrm{~h}$ dark. Seeds were put in Petri dishes with a diameter of $9 \mathrm{~cm}(20$ seeds for each replication, 5 replications) between two layers of filter paper $\left(73 \mathrm{~g} \cdot \mathrm{m}^{-2}\right)$ and wetted with $5 \mathrm{~mL}$ of distilled water to germinate. Petri dishes were sealed with Parafilm ${ }^{\circledR}$ and placed in the germination chamber for 15 days. Seeds germinated with percentages of around $75 \%$.

\subsection{Essential Oils (EOs)}

To test their herbicidal activity against E. bonariensis, Thymbra capitata (L.) Cav., Mentha piperita L., and Santolina chamaecyparissus L. EOs were purchased, respectively, from Bordas S.A., Sigma-Aldrich and Ecoaromuz. Eucalyptus camaldulensis Dehnh. EO is not commercially available and was obtained 
by hydrodistillation from fresh leaves collected from trees growing as ornamentals in the Turia River Gardens of Valencia, Spain.

To extract the oil, two Clevenger apparatus were used together with round-bottom flasks of 2 and $4 \mathrm{~L}$, heating mantles, and a condenser. After the fresh material was weighted with a precision scale, it was introduced in the flasks and $1000 \mathrm{~mL}$ (for the $2 \mathrm{~L}$ flask) or $2000 \mathrm{~mL}$ (for the $4 \mathrm{~L}$ flask) of distilled water were added. Heat was applied to the round-bottom flask by the heating mantle in order to generate water vapor carrying the volatile compounds of the drug. Then it was cooled in the condenser and passed to the graduated collector tube, where the essential oil was separated from the water. This process was carried out for at least $3 \mathrm{~h}$, ending when no more amount of oil was obtained for $30 \mathrm{~min}$. The yield of extraction was about $1.7 \mathrm{~mL}$ of EO per $100 \mathrm{~g}$ of leaves.

All EOs were kept in the refrigerator at $4{ }^{\circ} \mathrm{C}$ until they were used.

\subsection{Gas Chromatography (GC)}

The quantification of the EOs constituents was performed by gas chromatography using a Clarus 500GC Perkin-Elmer apparatus equipped with a flame ionization detector (FID), and a capillary column ZB-5 $(30 \mathrm{~m} \times 0.25 \mathrm{~mm}$ i.d. $\times 0.25 \mu \mathrm{m}$ film thickness). The injection volume was $1 \mu \mathrm{L}$. The GC oven temperature was set at $60^{\circ} \mathrm{C}$ for $5 \mathrm{~min}$, with $3{ }^{\circ} \mathrm{C}$ increases per min to $180{ }^{\circ} \mathrm{C}$, then $20^{\circ} \mathrm{C}$ increases per $\mathrm{min}$ to $280^{\circ} \mathrm{C}$, which was maintained for $10 \mathrm{~min}$. Helium was the carrier gas (1.2 $\left.\mathrm{mL} / \mathrm{min}\right)$. Injector and detector temperatures were set at $250^{\circ} \mathrm{C}$. The percentage composition of the $\mathrm{EO}$ was computed from GC peak areas without correction factors by means of the software Total Chrom 6.2 (Perkin-Elmer Inc., Wellesley, PA, USA).

\subsection{Gas Chromatography-Mass Spectrometry (GC-MS)}

For the identification of the compounds, gas chromatography coupled to mass spectrometry (GC-MS) was performed using a Clarus 500 GC-MS from Perkin-Elmer Inc. apparatus equipped with the same capillary column, carrier, and operating conditions as described above for GC analysis. The ionization source temperature was set at $200{ }^{\circ} \mathrm{C}$ and an electron impact mode of $70 \mathrm{eV}$ was employed. MS spectra were obtained by means of total ion scan (TIC) mode (mass range $m / z 45-500$ uma). The total ion chromatograms and mass spectra were processed with the Turbomass 5.4 software (Perkin-Elmer Inc.). Retention indexes were determined by injection of $\mathrm{C}_{8}-\mathrm{C}_{32} \mathrm{n}$-alkanes standard under the same conditions.

The EO components were identified by comparison of their mass spectra with those of the computer library NIST MS Search 2.0 and available data in the literature [61]. Identification of the following compounds was confirmed by comparison of their experimental RI with those of authentic reference standards (Sigma-Aldrich, Darmstadt, Germany): $\alpha$-pinene, $\beta$-pinene, camphene, myrcene, limonene, (Z)- $\beta$-ocimene, camphor, borneol, terpinen-4-ol, bornyl acetate, and linalool.

\subsection{Greenhouse Conditions}

All tests were conducted from 19 May to 24 August, 2017; the average temperature of the greenhouse was $27.3{ }^{\circ} \mathrm{C}$ with a maximum temperature of $36.5^{\circ} \mathrm{C}$ (August) and a minimum of $19.1^{\circ} \mathrm{C}$ (July). The relative humidity was between 24.8 and $93.4 \%$ (Table 4 ).

Table 4. Greenhouse temperature and relative humidity conditions during the experimental period.

\begin{tabular}{ccccccc}
\hline \multirow{2}{*}{ Month } & \multicolumn{3}{c}{ Temperature $\left({ }^{\circ} \mathbf{C}\right)$} & \multicolumn{2}{c}{ Relative Humidity (R.H.) \% } \\
\cline { 2 - 7 } & Mean & Maximum & Minimum & Mean & Maximum & Minimum \\
\hline May & 25.0 & 33.2 & 19.2 & 64.5 & 81.2 & 32.3 \\
June & 27.9 & 36.3 & 20.1 & 61.4 & 82.1 & 24.8 \\
July & 27.9 & 35.6 & 19.1 & 69.0 & 93.4 & 36.8 \\
August & 28.4 & 36.5 & 22.3 & 68.4 & 86.7 & 42.8 \\
\hline
\end{tabular}




\subsection{Pot Preparation}

For all experiments, pots of $8 \times 8 \times 7 \mathrm{~cm}$ were used, filled with $200 \mathrm{~g}$ of a substrate mixture of $\frac{3}{4}$ of peat moss and $\frac{1}{4}$ of perlite, previously homogenized.

\subsection{Pre-Emergence Herbicidal Tests}

Pots were irrigated with 2/3 of their water holding capacity (WHC), $60 \mathrm{~mL}$. Five seeds of E. bonariensis were placed in each pot, and 10 replicates were performed for each treatment, including controls. Treatments consisted of 4 EOs (T. capitata, M. piperita, E. camaldulensis, and S. chamaecyparissus), each of them distributed at three doses $(2,4$, and $8 \mu \mathrm{L} / \mathrm{mL})$, plus one control with water $(\mathrm{C} 1)$ and one control with water + Fitoil at $1 \mu \mathrm{L} / \mathrm{mL}(\mathrm{C} 2)$. Fitoil is a biological adjuvant with $40 \%$ soybean oil, used to emulsify the EOs with water, supplied by Xeda Italia s.r.l. After sowing, the remaining 1/3 of the WHC, $30 \mathrm{~mL}$ for each treatment was added to the corresponding pots.

During the experiment, which lasted 30 days, pots were irrigated three times per week.

The effects of the treatments on seed germination were tested by means of the germination measurements suggested by $[62,63]$. Pots were checked on a daily basis, and seeds were considered fully germinated after the full spreading of cotiledonary leaves. The daily count of every newly-germinated seed was used for determining the value of seed germination, further expressed as percentage (G\%). Mean germination time (MT), expressed in days, indicates the average length of time required for maximum germination of the tested seeds lot, and was calculated according to the following formula:

$$
\mathrm{MT}=\frac{\sum_{i=1}^{k} n_{i} t_{i}}{\sum_{i=1}^{k} n_{i}}
$$

where:

$t_{i}=$ days from the start of the experiment to the ith observation;

$n_{i}=$ number of seeds newly germinated in the ith day;

$\mathrm{k}=$ last day of germination.

The coefficient of variation of the germination time $(\mathrm{CVt})$ expressed in percentage was obtained as follows:

$$
\mathrm{CVt}=100 \mathrm{st} / \mathrm{MT} \text {, }
$$

where:

st = standard deviation of the germination time;

$\mathrm{MT}=$ mean germination time.

MR (mean germination rate) is the average number of seeds germinated in the time unit (in our case, one day), and is calculated as the reciprocal of MT.

The synchrony of the germination process was evaluated by means of the indices $U$ and $Z$.

$\mathrm{U}$ is the uncertainty of the germination process, i.e., the uncertainty associated with the distribution of the relative frequency of germination $\left(f_{\mathrm{i}}\right)$. It is expressed in bit (binary measurement), since it is based on the counts of the condition germinated/not germinated. It can assume values spanning from 0 and $\log _{2} n$, with $n$ being the total number of seeds germinated; low values of $U$ indicate frequencies with few peaks, i.e., a germination process that was more concentrated in time. The index U is calculated through the following formula:

$$
\mathrm{U}=-\sum_{i=1}^{k} f_{i} \log _{2} f_{i}
$$

where $f_{\mathrm{i}}$ is the relative frequency of germination, on its turn calculated as

$$
f_{\mathrm{i}}=\mathrm{n}_{\mathrm{i}} / \sum_{i=1}^{k} \mathrm{n}_{\mathrm{i}}
$$


$\mathrm{Z}$ is the synchrony of the germination process, i.e., a measurement of the degree of overlapping of seeds germination in time. It can take values from 0 (when at least two seeds germinated, in two different moments) to 1 (when all seeds germinated at the same time). It is calculated with the following formula:

$$
\mathrm{Z}=\sum \mathrm{C}_{n i, 2} / \mathrm{N}
$$

where $C_{n i, 2}$ is the combination of the seeds, two together, germinated in the time $\mathrm{i}$, and $\mathrm{N}$ is the sum of such combinations, along the whole experiment:

$$
\mathrm{N}=\sum n_{i}\left(\sum n_{i}-1\right) / 2
$$

All data were submitted to a two-way ANOVA, setting the six treatments $(\mathrm{T})$ as independent variables, including the controls and the EO doses (D) within each treatment. When the $F$ test gave a significant response, the differences among $T$ values were appreciated through the Tukey's test, whereas each dose within treatment $(\mathrm{D} \times \mathrm{T})$ value was compared with the respective value of the water control C1 (Dunnett's test) [64].

Percentage values were transformed into angular values, according to the following formula:

$$
\mathrm{Y}=\arcsin \sqrt{\mathrm{p}}
$$

where:

$$
\begin{aligned}
& \mathrm{Y}=\text { transformed value; } \\
& \mathrm{p}=\text { percentage }
\end{aligned}
$$

Before transformation, all zero values were substituted by $(1 / 4 n)$, where $n$ was the number of units upon which the percentage data was based (in our case, $\mathrm{n}=10$ ) [64]. The data reported in the table, however, are the original values.

\subsection{Post-Emergence Herbicidal Test}

The same treatments tested in pre-emergence were tested in post-emergence, using two different ways of applying them: watering or spraying in order to determine the best way to maximize the herbicidal activity of EOs. Each treatment was applied on E. bonariensis plants at the rosette phenological stage, that were previously produced from the same lot of seeds used for the pre-emergence trials. Ten repetitions (ten pots with one plant per pot) were used for each treatment. For both applications, $20 \mathrm{~mL}$ of each EO and dose were applied in the corresponding pots. The spraying was carried out with a manual trigger sprayer.

The first evaluation was made $24 \mathrm{~h}$ after treatment. Then, evaluations were carried out every five days, taking images of the pots that were later processed with the software Digimizer v.4.6.1 (MedCalc Software, Ostend, Belgium, 2005-2016). During the experiment, which lasted 30 days, pots were irrigated three times per week.

The diameter $(\mathrm{cm})$ of each plantlet was measured 1, 5, 10, 15, 20, 25, and 30 days after treatments application, including the controls with water and water + Fitoil, termed $\mathrm{Cw}$ and Cf, respectively. The phytotoxicity level (PL) of each treatment was assessed by determining the percent variations of growth of plantlets, both in treatments and in the controls, 1, 5, 10, 15, 20, 25, and 30 days after treatment, according to the following formula:

$$
\mathrm{PL}=\left(\mathrm{l}_{\mathrm{t} 1}-\mathrm{l}_{\mathrm{t} 2}\right) / \mathrm{l}_{\mathrm{t} 1} \times 100,
$$

where:

$1_{\mathrm{t} 1}=$ diameter $(\mathrm{cm})$ of plantlet at day $\mathrm{t}_{1}$;

$1_{\mathrm{t} 2}=$ diameter $(\mathrm{cm})$ of plantlet at day $\mathrm{t}_{2}$. 
As such, a PL $=100$ means complete inhibition effect (wilted plantlet), whereas a PL $<1$ means stimulation effect (growing plantlet, i.e., unaffected by the treatment).

All data were submitted to a multi-way ANOVA, setting as independent variables the method of application (M: watering or spraying), the day of survey (d: 1, 5, 10, 15, 20, 25, and 30 days after the treatment), the six treatments (T), including the controls and the EO doses within each treatment. The effect of the three doses was checked against the respective water control $(\mathrm{Cw})$ by means of the Dunnett's test, and this analysis was repeated separately for all survey dates and methods of application.

\section{Conclusions}

All the EOs tested significantly reduced E. bonariensis seed germination, ranking T. capitata $>E$. camaldulensis $>$ S. chamaecyparissus $>$ M. piperita. In post-emergence assays, T. capitata EO was the most effective in both administration ways, acting quicker when sprayed. E. camaldulensis EO was the second most effective but only when administrated by watering. The EOs of T. capitata, M. piperita, and E. camaldulensis demonstrated a high potential to control E. bonariensis and could be a source for the development of natural herbicides. It is important to highlight that the herbicidal activity of the EOs tested depended on the way they were administrated. It is necessary to develop adequate formulations to enhance the activity of the EOs and try them in field conditions.

Author Contributions: Conceptualization, M.V.; methodology, M.V., L.G.C. and N.T.-P.; software, M.V., L.G.C., N.T.-P., J.A.L.-M., and A.C.; validation, M.V., and A.C.; formal analysis, M.V., A.C. and J.A.L.-M.; investigation, M.V., L.G.C., N.T.-P. and J.A.L.-M.; resources, M.V.; data curation, M.V., and A.C.; writing-original draft preparation, M.V., and A.C.; writing-review and editing, M.V., and A.C.; visualization, M.V. and A.C.; supervision, M.V.; project administration, M.V.; funding acquisition, M.V. All authors have read and agreed to the published version of the manuscript.

Funding: This research received no external funding.

Conflicts of Interest: The authors declare no conflict of interest.

\section{References}

1. United Nations, Department of Economic and Social Affairs, Population Division. World Population Prospects: The 2017 Revision, Key Findings and Advance Tables; Working Paper No. ESA/P/WP/248; United Nations: New York, NY, USA, 2017.

2. Hüter, O.F. Use of natural products in the crop protection industry. Phytochem. Rev. 2011, 10, 185-194. [CrossRef]

3. Savary, S.; Ficke, A.; Aubertot, J.; Hollier, C. Crop losses due to diseases and their implications for global food production losses and food security. Food Secur. 2012, 4, 519-537. [CrossRef]

4. Oerke, E.C. Crop losses to pests. J. Agric. Sci. 2006, 144, 31-43. [CrossRef]

5. Monaco, T.J.; Weller, S.C.; Ashton, F.M. Weed Science: Principles and Practices; John Wiley \& Sons, Inc.: New York, NY, USA, 2002.

6. Troyer, J.R. In the beginning: The multiple discovery of the first hormone herbicides. Weed Sci. 2001, 49, 290-297. [CrossRef]

7. Catalá, R.; Salinas, J. Tailoring crop nutrition to fight weeds. Proc. Natl. Acad. Sci. USA 2018, 115, 7456-7458. [CrossRef]

8. Abbas, T.; Zahir, Z.A.; Naveed, M.; Kremer, R.J. Limitations of existing weed control practices necessitate development of alternative techniques based on biological approaches. Adv. Agron. 2018, 147, 239-280.

9. World Health Organization and Food; Agriculture Organization of the United Nations. The International Code of Conduct on Pesticide Management; Rome, Italy, 2014. Available online: http://www.fao.org/3/a-i3604e.pdf (accessed on 23 November 2019).

10. Villa, F.; Cappitelli, F.; Cortesi, P.; Kunova, A. Fungal Biofilms: Targets for the Development of Novel Strategies in Plant Disease Management. Front. Microbiol. 2017, 8, 654-664. [CrossRef]

11. Manker, D.C. Natural products as green pesticides. In New Discoveries in Agrochemicals; Clark, J.M., Ohkawa, H., Eds.; American Chemical Society: Washington, DC, USA, 2005; pp. 283-294. 
12. Benvenuti, S.; Cioni, P.L.; Flamini, G.; Pardossi, A. Weeds for weed control: Asteraceae essential oils as natural hericides. Weed Res. 2017, 57, 342-353. [CrossRef]

13. Tworkoski, T. Herbicide effects of essential oils. Weed Sci. 2002, 50, 425-431. [CrossRef]

14. Verdeguer, M.; Blazquez, M.A.; Boira, H. Phytotoxic effects of Lantana camara, Eucalyptus camaldulensis and Eriocephalus africanus essential oils in weeds of Mediterranean summer crops. Biochem. Syst. Ecol. 2009, 37, 362-369. [CrossRef]

15. Singh, H.P.; Batish, D.R.; Setia, N.; Kohli, R.K. Herbicidal activity of volatile oils from Eucalyptus citriodora against Parthenium hysterophorus. Ann. Appl. Biol. 2005, 146, 89-94. [CrossRef]

16. Angelini, L.G.; Carpanese, G.; Cioni, P.L.; Morelli, I.; Macchia, M.; Flamini, G. Essential oils from Mediterranean lamiaceae as weed germination inhibitors. J. Agric. Food. Chem. 2003, 51, 6158-6164. [CrossRef] [PubMed]

17. Frabboni, L.; Tarantino, A.; Petruzzi, F.; Disciglio, G. Bio-Herbicidal Effects of Oregano and Rosemary Essential Oils on Chamomile (Matricaria chamomilla L.) Crop in Organic Farming System. Agronomy (Basel) 2019, 9, 475. [CrossRef]

18. Bajwa, A.A.; Sadia, S.; Ali, H.H.; Jabran, K.; Peerzada, A.M.; Chauhan, B.S. Biology and management of two important Conyza weeds: A global review. Environ. Sci. Poll. Res. 2016, 23, 24694-24710. [CrossRef]

19. Michael, P.W. Some weedy species of Amaranthus (amaranths) and Conyza/Erigeron (fleabanes) naturalised in the Asian-Pacific region. In Proceedings of the 6th Asian-Pacific Weed Science Society Conference, Jakarta, Indonesia, 11-17 July 1977; Asian-Pacific Weed Science Society: Jakarta, Indonesia, 1977; pp. 87-95.

20. Trezzi, M.M.; Balbinot, A.A., Jr.; Benin, G.; Debastiani, F.; Patel, F.; Miotto, E., Jr. Competitive ability of soybean cultivars with horseweed (Conyza bonariensis). Planta Daninha 2013, 31, 543-550. [CrossRef]

21. Ferreira, E.A.; Galon, L.; Aspiazu, I.; Silva, A.A.; Concenco, G.; Silva, A.F.; Oliveira, J.A.; Vargas, L. Glyphosate translocation in hairy fleabane (Conyza bonariensis) biotypes. Planta Daninha 2008, 26, 637-643. [CrossRef]

22. Wu, H.; Walker, S.; Rollin, M.J.; Tan, D.K.Y.; Robinson, G.; Werth, J. Germination, persistence, and emergence of flaxleaf fleabane (Conyza bonariensis [L.] Cronquist). Weed Biol. Manag. 2007, 7, 192-199. [CrossRef]

23. Widderick, M.; Walker, S.; Cook, T. Flaxleaf fleabane (Conyza bonariensis)-strategic solutions using best management practice. Pak. J. Weed Sci. Res. 2012, 18, 687-693.

24. Bhowmik, P.C.; Bekech, M.M. Horseweed (Conyza canadensis) seed production, emergence and distribution in no-tillage and conventional-tillage corn (Zea mays). Agron. Trends Agric. Sci. 1993, 11, 67-71.

25. Wu, H.; Walker, S.; Robinson, G.; Coombes, N. Control of flaxleaf fleabane (Conyza bonariensis) in wheat and sorghum. Weed Technol. 2010, 24, 102-107. [CrossRef]

26. Moreira, M.S.; Nicolai, M.; Carvalho, S.J.P.; Christoffoleti, P.J. Resistência de Conyza canadensis e C. bonariensis ao herbicida glyphosate. Planta Daninha 2007, 25, 157-164. [CrossRef]

27. Heap, I. The International Survey of Herbicide Resistant Weeds. Available online: www.weedscience.org. (accessed on 16 November 2019).

28. Garcia Plasencia, S. Actividad herbicida del aceite esencial de Thymus capitatus (L.) Hoffmanns. et Link. y su efectividad en función de distintos métodos de aplicación. Master's Thesis, Universitat Politècnica de València, Valencia, Spain, 24 September 2013.

29. Hanana, M.; Mansour, M.B.; Algabr, M.; Amri, I.; Gargouri, S.; Romane, A.; Jamoussi, B.; Hamrouni, L. Potential use of essential oils from four Tunisian species of Lamiaceae: Biological alternative for fungal and weed control. Rec. Nat. Prod. 2017, 11, 258-269.

30. Verdeguer, M. Fitotoxicidad de Aceites Esenciales y Extractos Acuosos de Plantas Mediterráneas para el Control de Arvenses. Ph.D. Thesis, Universitat Politècnica de València, Valencia, Spain, 14 October 2011.

31. Mahdavikia, F.; Saharkhiz, M.J. Phytotoxic activity of essential oil and water extract of peppermint (Menthaxpiperita L. CV. Mitcham). J. Appl. Res. Med. Aromat. Plants 2015, 2, 146-153. [CrossRef]

32. Miceli, A.; Negro, C.; Tommasi, L. Essential oil variability in Thymbra capitata (L.) Cav. growing wild in Southern Apulia (Italy). Biochem. Syst. Ecol. 2006, 34, 528-535. [CrossRef]

33. Fleisher, Z.; Fleisher, A. Volatiles of Coridothymus capitatus Chemotypes Growing in Israel: Aromatic Plants of the Holy Land and the Sinai. Part XV J. Essent. Oil Res. 2002, 14, 105-106. [CrossRef]

34. Hedhili, L.; Romdhane, M.; Abderrabba, M.; Planche, H.; Cherif, I. Variability in essential oil composition of Tunisian Thymus capitatus (L.) Hoff. et Link. Flavour Frag. J. 2002, 17, 26-28. [CrossRef] 
35. Saoud, I.; Hamrouni, L.; Gargouri, S.; Amri, I.; Hanana, M.; Fezzani, T. Chemical composition, weed killer and antifungal activities of Tunisian thyme (Thymus capitatus Hoff. et Link.) essential oils. Acta Aliment. Hung. 2013, 42, 417-427. [CrossRef]

36. Ibáñez, M.D.; Blázquez, M.A. Herbicidal value of essential oils from oregano-like flavour species. Food Agric. Immunol. 2017, 28, 1168-1180. [CrossRef]

37. Pinheiro, P.F.; Costa, A.V.; Alves, T.D.A. Phytotoxicity and cytotoxicity of essential oil from leaves of Plectranthus amboinicus, carvacrol, and thymol in plant bioassays. J. Agric. Food Chem. 2015, 63, 8981-8990. [CrossRef]

38. Vasilakoglou, I.; Dhima, K.; Paschalidis, K.; Christos, R. Herbicidal potential on Lolium rigidum of nineteen major essential oil components and their synergy. J. Essent. Oil Res. 2013, 25, 1-10. [CrossRef]

39. Vokou, D.; Douvli, P.G.; Blionis, J.; Halley, J.M. Effects of monoterpenoids, acting alone or in pairs, on seed germination and subsequent seedling growth. J. Chem. Ecol. 2003, 29, 2281-2301. [CrossRef] [PubMed]

40. Martino, L.D.; Mancini, E.; de Almeida, L.F.R.; Feo, V.D. The antigerminative activity of twenty-seven monoterpenes. Molecules 2010, 15, 6630-6637. [CrossRef] [PubMed]

41. Chaimovitsh, D.; Shachter, A.; Abu-Abied, M.; Rubin, B.; Sadot, E.; Dudai, N. Herbicidal activity of monoterpenes is associated with disruption of microtubule functionality and membrane integrity. Weed Sci. 2017, 65, 19-30. [CrossRef]

42. Brahmi, F.; Khodir, M.; Mohamed, C.; Pierre, D. Chemical composition and biological activities of Mentha species. In Aromatic and Medicinal Plants—Back to Nature; InTech: London, UK, 2017; pp. 47-80.

43. Soković, M.D.; Glamočlija, J.; Marin, P.D.; Brkić, D.D.; Vukojević, J.; Jovanović, D.; Bulajić, N.; Kataranovski, D. Antifungal Activity of the Essential Oil of Mentha $\times$ piperita. Pharm. Biol. 2006, 44, 511-515. [CrossRef]

44. Desam, N.R.; Al-Rajab, A.J.; Sharma, M.; Mylabathula, M.M.; Gowkanapalli, R.R.; Albratty, M. Chemical constituents, in vitro antibacterial and antifungal activity of Mentha $\times$ Piperita, L. (peppermint) essential oils. J. King Saud Univ. Sci. 2017, 31, 528-533. [CrossRef]

45. Synowiec, A.; Drozdek, E. Physicochemical and herbicidal properties of emulsions of essential oils against Avena fatua L. and Chenopodium album L. J. Plant. Dis. Prot. 2016, 123, 65-74. [CrossRef]

46. Maffei, M.; Wanda, C.; Silvano, S. Effect of Mentha $\times$ piperita essential oil and monoterpenes on cucumber root membrane potential. Phytochemistry 2001, 58, 703-707. [CrossRef]

47. Skrzypek, E.; Repka, P.; Stachurska-Swakon, A.; Barabasz-Krasny, B.; Mozdzen, K. Allelopathic effect of aqueous extracts from the leaves of peppermint (Mentha $\times$ piperita L.) on selected physiological processes of common sunflower (Helianthus annuus L.). Not. Bot Horti. Agrobo. 2015, 43, 335-342. [CrossRef]

48. Campiglia, E.; Mancinelli, R.; Cavalieri, A.; Caporali, F. Use of essential oils of cinnamon (Cinnamomum zeylanicum L.), lavender (Lavandula spp.) and peppermint (Mentha $\times$ piperita L.) for weed control. Ital. J. Agron. 2007, 58, 171-175. [CrossRef]

49. Pappas, R.S.; Sheppard-Hanger, S. Essential oil of Eucalyptus camaldulensis Dehn. from south Florida: A high cryptone/low cineole eucalyptus. J. Essent. Oil Res. 2000, 12, 383-384. [CrossRef]

50. Chalchat, J.C.; Kundakovic, T.; Gorunovic, M.S. Essential oil from leaves of Eucalyptus camaldulensis Dehn, Myrtaceae from Jerusalem. J. Essent. Oil Res. 2001, 13, 105-107. [CrossRef]

51. Tsiri, D.; Kretsi, O.; Chinou, I.B.; Spyropoulos, C.G. Composition of fruit volatiles and annual changes in the volatiles of leaves of Eucalyptus camaldulensis Dehn. Growing in Greece. Flavour Fragr. J. 2003, 18, 244-247. [CrossRef]

52. Üstüner, T.; Kordali, S.; Bozhüyük, A.U. Investigation of pesticidal activities of essential oil of Eucalyptus camaldulensis Dehnh. Rec. Nat. Prod. 2018, 12, 557-568. [CrossRef]

53. Fouad, R.; Bousta, D.; Lalami, A.E.; Chahdi, F.O.; Amri, I.; Jamoussi, B.; Greche, H. Chemical composition and herbicidal effects of essential oils of Cymbopogon citratus (DC) Stapf, Eucalyptus cladocalyx, Origanum vulgare L and Artemisia absinthium L cultivated in Morocco. J. Essent. Oil Bear. Plants 2015, 18, 112-123. [CrossRef]

54. Vernin, G. Volatile constituents of the essential oil of Santolina chamaecyparissus L. J. Essent. Oil Res. 1991, 3, 49-53. [CrossRef]

55. Perez-Alonso, M.J.; Velasco-Negueruela, A. Essential oil components of Santolina chamaecyparissus. Flavour Fragrance J. 1992, 7, 37-41. [CrossRef]

56. Derbesy, M.; Touche, J.; Zola, A. The essential oil of Santolina chamaecyparissus L. J. Ess. Oil Res. 1989, 1, 269-275. [CrossRef] 
57. Grosso, C.; Coelho, J.A.; Urieta, J.S.; Palavra, A.M.F.; Barroso, J.G. Herbicidal activity of volatiles from coriander, winter savory, cotton lavender, and thyme isolated by hydrodistillation and supercritical fluid extraction. J. Agric. Food Chem. 2010, 58, 11007-11013. [CrossRef]

58. Garg, S.N.; Gupta, D.; Mehta, V.K.; Kumar, S. Volatile Constituents of the Essential Oil of Santolina chamaecyparissus Linn, from the Southern Hills of India. J. Essent. Oil Res. 2001, 13, 234-235. [CrossRef]

59. De Elguea-Culebras, G.O.; Sanchez-Vioque, R.; Berruga, M.I.; Herraiz-Penalver, D.; Gonzalez-Coloma, A.; Andres, M.F.; Santana-Meridas, O. Biocidal potential and chemical composition of industrial essential oils from Hyssopus officinalis, Lavandula $\times$ intermedia var. super, and Santolina chamaecyparissus. Chem. Biodivers. 2018, 15, 1-9. [CrossRef]

60. Carretero, J.L. Flora Arvense Española: Las Malas Hierbas de los Cultivos Españoles; Phytoma: Valencia, España, 2004.

61. Adams, R.P. Identification of Essential Oil Components by Gas Chromatography/Mass Spectrometry, 4th ed.; Allured Publishing Corporation: Carol Stream, IL, USA, 2007.

62. Ranal, M.A.; Garcia De Santana, D. How and why to measure the germination process? Revista Brasil. Bot. 2006, 29, 1-11. [CrossRef]

63. Ranal, M.A.; Garcia De Santana, D.; Resende Ferreira, W.; Mendes-Rodrigues, C. Calculating germination measurements and organizing spreadsheets. Revista Brasil. Bot. 2009, 32, 849-855. [CrossRef]

64. Steel, R.G.D.; Torrie, J.H. Principles and Procedures of Statistics: A Biometrical Approach, 2nd ed.; McGraw-Hill: New York, NY, USA, 1980.

Sample Availability: Samples of the essential oils tested are available from the authors.

(C) 2020 by the authors. Licensee MDPI, Basel, Switzerland. This article is an open access article distributed under the terms and conditions of the Creative Commons Attribution (CC BY) license (http://creativecommons.org/licenses/by/4.0/). 